\title{
Representações da Argentina imperialista - 0 antiperonismo na imprensa e na diplomacia brasileiras (1946-1950)
}

\author{
Rodolpho Gauthier Cardoso dos Santos ${ }^{1}$ \\ Iuri Cavlak ${ }^{2}$
}

\begin{abstract}
Resumo: $O$ artigo analisa representações negativas a respeito da Argentina peronista difundidas na segunda metade da década de 1940, especialmente as produzidas pela imprensa e pela diplomacia brasileiras. No primeiro caso, são investigadas principalmente as reportagens veiculadas pela revista ilustrada $O$ Cruzeiro. Em relação à diplomacia, foram examinados os ofícios produzidos pela Embaixada brasileira naquele país. A leitura dessas fontes, que possuem especificidades, destaca uma característica semelhante: a construção frequente de imagens a respeito de um vizinho imperialista que, inspirado pelo nazifascismo, preparava-se para a guerra com objetivo de reconstruir as fronteiras do vice-reinado do Rio da Prata, que existiu no período colonial. Interessa aqui compreender e questionar tais representações à luz da historiografia e do contexto político do Cone Sul e do mundo, que havia recentemente passado pela débacle das experiências políticas nazifascistas na Europa e vivenciava os primeiros anos da Guerra Fria.
\end{abstract}

Palavras-chave: Antiperonismo; Imprensa; Diplomacia.

\section{Representations of the imperialist Argentina - the anti-Peronism in the Brazilian press and diplomacy (1946-1950)}

\begin{abstract}
The article analyzes some negative representations about Peronist Argentina spread in the second half of the 1940s, especially those produced by Brazilian press and diplomacy. In the first case, we investigate especially the reports conveyed by the illustrated magazine $O$ Cruzeiro. In relation to diplomacy, we examined the offices produced by the Brazilian Embassy in that country. The reading of these sources, which have specificities, highlights a similar characteristic: the frequent construction of images about an imperialist neighbor who, inspired by Nazi-fascism, was preparing for the war with the objective of rebuilding the borders of the Vice-Reign of Rio da Prata, which existed in the colonial period. Here we are interested in understanding and questioning

\footnotetext{
${ }^{1}$ Doutor em História Social pela Universidade de São Paulo (USP). Professor do Instituto Federal de Minas Gerais (IFMG), campus Ouro Branco. O presente artigo desenvolve reflexões oriundas da tese de doutorado, que teve orientação da Profa. Dra. Maria Helena Rolim Capelato. E-mail do autor: rodolpho.santos@ifmg.edu.br

${ }^{2}$ Doutor em História pena Unesp de Assis. Professor do Colegiado de História da Universidade Federal do Amapá (UNIFAP). O artigo desenvolve algumas reflexões de minha tese de doutorado, orientada pelo Prof. José Luís Beired. Email do autor: iuricavlak@yahoo.com.br
}

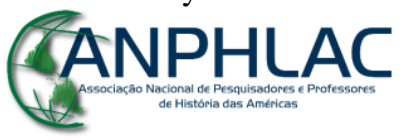

Revista Eletrônica da ANPHLAC, ISSN 1679-1061, №. 22, p. 258-295, Jan./Jun., 2017.

http://revista.anphlac.org.br 
such representations in light of the historiography and political context of the Southern Cone and the world, which had recently undergone the debacle of Nazi-fascist political experiences in Europe and was experiencing the early years of the Cold War.

Key Words: Anti-Peronism; Press; Diplomacy.

Artigo recebido em: 31/10/2016

Artigo aprovado para publicação em: 09/02/2017

\section{Introdução}

Este artigo analisa as representações negativas a respeito da política externa argentina entre os anos 1946 a 1950, período em que o país foi governado pelo coronel Juan Domingo Perón (1895-1974). Concentra-se em examinar fontes históricas produzidas por dois grupos sociais bastante diferentes - jornalistas e diplomatas brasileiros. Curiosamente, esses dois setores tenderam a idealizar seu trabalho como algo acima das paixões político-partidárias e que se realiza em nome do bem comum. Tal discurso não se sustenta no caso analisado, como se buscará demonstrar.

Parte dos estudos acadêmicos recentes coincide ao apontar que a política externa peronista não foi expansionista. Sua estratégia consistia, nas palavras de Moniz Bandeira (2010, p. 242), mais em "ganhar simpatia e respeito [do que] antagonizar ou agredir os países vizinhos". De acordo com o sociólogo argentino José Paradiso (2002, p. 566), artigos escritos por Perón mostram que ele realmente acreditava na integração entre os países sul-americanos para garantir ganhos econômicos mútuos e contrabalançar a influência dos Estados Unidos. Desse modo, suas ideias passariam longe do objetivo de reconstruir as fronteiras do Vice-Reinado do Rio da Prata, colônia espanhola que durante o período colonial tivera Buenos Aires como capital.

Se a Argentina peronista não liderou conflitos armados para expandir seus domínios, por que a preocupação em relação ao imperialismo da Casa Rosada foi constante em diversos meios de comunicação e nos documentos diplomáticos brasileiros do período? Essa é uma questão que tentaremos responder nas páginas

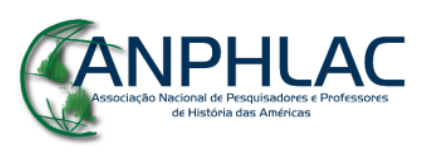

Revista Eletrônica da ANPHLAC, ISSN 1679-1061, №. 22, p. 258-295, Jan./Jun., 2017.

http://revista.anphlac.org.br 
seguintes. As fontes levantadas ajudam a compreender os desencontros diplomáticos das duas nações naqueles anos. Parte-se do pressuposto de que, de formas distintas, tanto a diplomacia quanto a grande imprensa contribuíram para que nesse momento o medo de um ataque argentino prevalecesse sobre perspectivas de acordos de cooperação.

Vale destacar que estudos sobre o antiperonismo vêm ganhando fôlego na historiografia argentina nas últimas décadas. ${ }^{3}$ No entanto, ainda são poucos os trabalhos que tratam dessa questão envolvendo países vizinhos, como o Brasil. ${ }^{4}$ Esse objeto de estudo relativamente recente pode trazer novas perspectivas às análises das relações internacionais e da história política envolvendo os dois países.

Antes da análise das fontes, cabe esclarecer alguns aspectos históricos importantes daquele momento. Em 1943, durante a Segunda Guerra Mundial, um golpe de Estado na Argentina levou ao poder militares de viés nacionalista, anticomunista e ultracatólico. Entre os oficiais do Grupo de Oficiales Unidos ou Grupo Obra de Unificación (GOU), destacou-se o coronel Juan Domingo Perón que aos poucos acumulou os cargos de vice-presidente, Ministro da Guerra e Secretário do Trabalho. (TORRE, 2012)

Foi nessa última atividade que Perón começou a construir uma aliança com as classes trabalhadoras por meio da Confederación General del Trabajo (CGT). Estabeleceu, entre outras medidas, férias remuneradas, indenização por acidentes de trabalho e o aguinaldo, remuneração extra no final do ano (equivalente ao $13^{\circ}$ salário no Brasil). Entretanto, enfrentou forte oposição de entidades patronais poderosas como a Unión Industrial Argentina (UIA) e a Sociedad Rural Argentina (SRA). Foi alvo, ainda, de agremiações e partidos liberais, vinculados à classe média e a estudantes universitários, que combatiam a ditadura do GOU e a associavam ao nazifascismo.

\footnotetext{
3 Podem ser citados: SPINELLI, María Estela. Los vencedores vencidos. El antiperonismo y la "revolución libertadora". Buenos Aires, Biblos, 2005; NÁLLIN, Jorge A. Las raíces del antiperonismo. Orígenes históricos e ideológicos. Buenos Aires: Capital Intelectual, 2014; SEBASTIANI, Marcela García. Los antiperonistas en la Argentina peronista. Radicales y socialistas en la política argentina entre 1943 y 1951. Buenos Aires, Prometeo Libros, 2005.

${ }^{4}$ Pode-se citar: SAAVEDRA, Marisol. Peronismo y antiperonismo en Chile y Brasil. Todo es Historia, $\mathrm{n}^{\circ}$ 369, abril de 1998, p. 8-34; BOHOSLAVSKY, Ernesto. Antivarguismo y antiperonismo (1943-1955): similitudes, diferencias y vínculos. Anuario digital (Esc. Historia, F., H. y A. de la UNR), Universidad Nacional de Rosário, no. 24, 2012, p. 73-97.
}

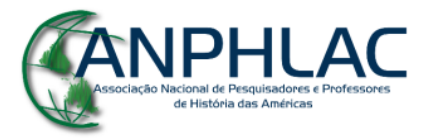

Revista Eletrônica da ANPHLAC, ISSN 1679-1061, №. 22, p. 258-295, Jan./Jun., 2017. http://revista.anphlac.org.br 
Neutra durante a maior parte da Segunda Guerra Mundial, a Argentina declarara guerra ao Eixo apenas um mês antes do suicídio de Hitler e da rendição alemã.

Com o final do conflito, a pressão pela redemocratização se avolumou e, após um período interno bastante tenso, eleições presidenciais foram marcadas para fevereiro de 1946. Durante a campanha, Perón, que atingira considerável popularidade, articulou uma coligação que teve como base a CGT, o Exército, a Igreja Católica e grupos conservadores nacionalistas que apoiaram o recém-criado Partido Laborista (PL). A oposição, que lançou José Tamborini, foi apoiada por diversos partidos (incluindo o radical, o socialista e o comunista) e entidades patronais. Tratava-se de uma aliança eleitoral ampla, intitulada Unión Democrática, que enfatizava em seus discursos a luta pela democracia e contra o autoritarismo do regime de 1943, do qual Perón era apontado como grande herdeiro.

Em um conhecido episódio ocorrido dias antes do pleito, Spruille Braden, embaixador dos Estados Unidos na Argentina, ajudou a divulgar amplamente o "Libro Azul", um relatório detalhado com documentos que vinculavam Perón e pessoas próximas a ele ao nazismo durante a guerra. A interferência dos Estados Unidos no processo político argentino foi habilmente utilizada por Perón, que argumentou que seus concorrentes eram grandes oligarcas e títeres da potência capitalista. Invocando a necessidade de defender a pátria contra o imperialismo, ele lançou o "Libro Azul y Blanco" (cores da bandeira argentina), com documentos que negavam suas ligações com os alemães. E pediu ironicamente aos eleitores que escolhessem nas urnas entre "Braden ou Perón". (CAPELATO, 2008, p. 269) O slogan antiimperialista funcionou. Em fevereiro de 1946, ocorreram eleições num clima de relativa tranquilidade e respeito às instituições democráticas. Perón foi eleito com pouco mais de $52 \%$ dos votos.

No Brasil, Getúlio Vargas dera início à transição democrática em maio de 1945. Havia forte insatisfação de diversos setores sociais e das Forças Armadas com o autoritarismo do Estado Novo instaurado desde 1937. Além disso, a vitória dos Aliados fortaleceu a propagação das democracias liberais. Nesse contexto, o surgimento do movimento queremista, que reivindicava uma Constituinte com a participação do

\section{CANPHLAC}

Revista Eletrônica da ANPHLAC, ISSN 1679-1061, №. 22, p. 258-295, Jan./Jun., 2017.

http://revista.anphlac.org.br 
presidente gaúcho, tornou-se uma preocupação para os antivarguistas, pois poderia significar a continuidade do regime.

Em 29 de outubro, porém, o Estado Novo foi derrubado pelas Forças Armadas. Semanas depois, o general Eurico Gaspar Dutra, um militar de viés mais conservador do que Vargas, foi eleito democraticamente para um mandato de cinco anos (1946-1951). Nesse período, 143 sindicatos sofreram intervenções do governo e houve forte alinhamento diplomático com os Estados Unidos no início da Guerra Fria. Em 1947, o Tribunal Superior Eleitoral cassou o registro do Partido Comunista Brasileiro (PCB) e, no ano seguinte, todos os parlamentares vermelhos perderam seus mandatos.

Enquanto isso, a Argentina peronista passou a se opor cada vez mais ao sistema geopolítico sob a tutela estadunidense. Embora anticomunista, Perón restabeleceu relações diplomáticas com a União Soviética apenas alguns dias depois de chegar à Presidência. Ele declarou em 1947 a "Terceira posição" da Argentina em relação à Guerra Fria. Buscaria, sobretudo no nível do discurso, mostrar distanciamento em relação à política tanto dos Estados Unidos quanto da União Soviética. ${ }^{5}$

O país possuía então muitas reservas, acumuladas em decorrência dos saldos comerciais positivos obtidos durante a guerra. Esses recursos financiaram a política peronista de distribuição de renda e de forte intervenção do Estado na economia, que incluiu a nacionalização de ferrovias e de serviços, como o fornecimento de energia elétrica, telefonia e gás. Houve aumento do poder de compra dos trabalhadores, o que gerou grande entusiasmo de parte da população. Aproveitando-se do bom momento, o peronismo liderou uma ampla reforma da Constituição em 1949 que incorporou direitos sociais e garantiu a Perón ilimitadas tentativas de reeleição.

Segundo José Paradiso (2002, p. 528-529), o final da guerra trouxera facetas contraditórias à Argentina. De um lado, o país acumulara grande saldo comercial ao abastecer nações em conflito; de outro, havia ficado praticamente isolada da

\footnotetext{
${ }^{5}$ Ao contrário do Brasil, o Partido Comunista argentino não foi proscrito em nenhum momento. Isso não evitou que os comunistas argentinos, bem como partidários de outras agremiações, sofressem com perseguições, prisões dos seus correligionários e fechamento de alguns de seus jornais. Tal qual Vargas, Perón fez uso do imaginário anticomunista em vários momentos. Costumava lembrar aos empresários que as medidas de cunho social tomadas pelo Estado eram a melhor forma de evitar a repetição dos acontecimentos russos de 1917.
}

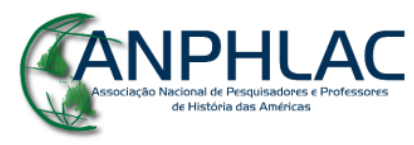

Revista Eletrônica da ANPHLAC, ISSN 1679-1061, №. 22, p. 258-295, Jan./Jun., 2017. http://revista.anphlac.org.br 
comunidade internacional. Por ter declarado guerra ao Eixo apenas em março de 1945 e ter se oposto continuamente aos interesses dos Estados Unidos, o governo argentino "não podia livrar-se facilmente do peso que supunha ser visto como herdeiro de um regime militar pró-fascista".

Colaborou para essa imagem a ampla e bem articulada estrutura de propaganda peronista, que incluía controle sobre grande número de meios de comunicação. Os jornais críticos ao governo sofreram duramente com restrições de papel, processos judiciais e outras formas de intimidação e intervenção. Nas rádios, havia a obrigatoriedade de transmissão diária dos discursos do casal presidencial em um boletim de trinta minutos. Além disso, o regime incorporou, direta ou indiretamente, 23 jornais e 19 estações de rádio. De acordo com a historiadora Maria Helena Capelato (2008, p. 76-77 e 95), os organizadores da propaganda peronista foram atentos observadores da política de propaganda nazifascista e adotaram os métodos de persuasão usados na Alemanha e na Itália, adaptando-os. Durante o primeiro mandato (1946-1951), houve grande fortalecimento do Poder Executivo e limitação das liberdades políticas que resultaram na prisão de opositores e censura aos meios de comunicação.

Para romper o relativo isolamento diplomático, a política externa argentina adotou uma postura bastante ativa e pragmática, que culminou, até o ano de 1950, na assinatura de mais de 120 acordos comerciais com diversas nações, muitas delas da América do Sul. (CAVLAK, 2008, p. 24)

Enquanto o general Eurico Gaspar Dutra esteve na presidência, a diplomacia argentina tentou, em inúmeras ocasiões, uma aproximação maior com o Brasil, seu terceiro maior parceiro comercial. O resultado, no entanto, ficou aquém do esperado. Ainda que Dutra, Perón e Evita tenham se encontrado em Uruguaiana-RS em 1947, não existiram grandes avanços em termos diplomáticos e políticos no sentido de estreitamento de laços entre os dois países. A política externa dutrista, ao incorporar diretrizes de Washington, adotou uma postura de obstrução à integração regional que dificultou o fechamento de acordos de cooperação. (CAVLAK, 2008, p. 56-57) Além disso, tais iniciativas eram fortemente rejeitadas por parte da imprensa brasileira, pelo

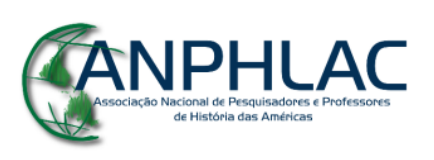

Revista Eletrônica da ANPHLAC, ISSN 1679-1061, №. 22, p. 258-295, Jan./Jun., 2017.

http://revista.anphlac.org.br 
principal partido antivarguista, a União Democrática Nacional (UDN), e por um setor do próprio Itamaraty (Ministério das Relações Exteriores), órgão com quadros de coloração política geralmente conservadora e que não viam com bons olhos a experiência social peronista.

Ciente de que lhe atribuíam intuitos beligerantes, Perón promoveu, a partir de 1947, uma intensa campanha pela paz em vários países. Esta se deu especialmente a partir da divulgação de uma série de artigos em que o líder argentino defendia que o justicialismo poderia ser uma opção diante do enfrentamento entre capitalismo e comunismo. Perón afirmava que o segundo era efeito do primeiro e que a Argentina havia superado ambos por meio de uma terceira via pacifista, o justicialismo. Ainda que tal campanha tenha conseguido considerável alcance, nas palavras de José Paradiso (2002, p. 537-538), “ela não era suficiente para neutralizar os efeitos do preconceito antiargentino e tampouco foi possível impedir que tal iniciativa fosse interpretada como parte de um propósito propagandístico menos interessado do que o que lhe atribuía seus inspiradores". Assim, apesar dos esforços de propaganda pacifista e de não ter mobilizado tropas para nenhum conflito, a representação do regime peronista como intrinsecamente bélico permaneceu forte por muitos anos.

\title{
O imperialismo justicialista representado na imprensa
}

\begin{abstract}
A imprensa brasileira é contrária ao nosso país. Apesar disso, acredito que é possível fazer um trabalho eficaz de aproximação, pelo menos com os seus mais competentes representantes. A exceção fica por conta, em forma radical e permanente, de dois setores perfeitamente identificados do jornalismo local: a cadeia dos Diários Associados (Assis Chateaubriand) e Tribuna da Imprensa (Carlos Lacerda). (...) A importância de ambas as empresas sobre a política externa está no fato de que, por pressão ideológica, conseguem influenciar outros jornais a atacar assuntos argentinos, difundindo o espírito característico da oposição que logo transcende o resto das esferas governamentais. (Nota secreta da Embaixada argentina no. 888 de 27/07/1954 apud ALMEIDA, 2005, p. 149-150)
\end{abstract}

Esse trecho integra uma nota secreta produzida pela embaixada argentina no Rio de Janeiro. Apesar de tratar de um período posterior ao analisado aqui, pode-se imaginar que a situação entre 1946 e 1950 fosse semelhante.

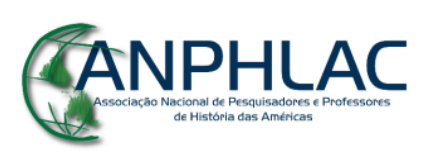

Revista Eletrônica da ANPHLAC, ISSN 1679-1061, №. 22, p. 258-295, Jan./Jun., 2017.

http://revista.anphlac.org.br 
Amplamente majoritária em termos de leitores, a grande parte da imprensa foi crítica, na maioria das vezes, ao peronismo. Sob forte influência das agências de notícias internacionais ${ }^{6}$, seus argumentos estiveram com frequência vinculados principalmente à defesa dos direitos individuais, em especial da liberdade de expressão. Inúmeras reportagens, editoriais e charges foram veiculados para denunciar o crescente autoritarismo do justicialismo. Sob tal prisma, esses meios de comunicação se colocavam como paladinos do liberalismo. Ao mesmo tempo, porém, a análise dessas fontes mostra, de modo geral, uma profunda rejeição à participação popular mais ampla e à extensão dos direitos sociais. Insistentemente, as medidas trabalhistas do governo argentino foram descritas como mera demagogia, o que mostra a postura conservadora de tais meios de comunicação. Resulta desses aspectos a definição, aparentemente contraditória, de uma imprensa liberal-conservadora. ${ }^{7}$ Nela, a defesa apaixonada da democracia e da liberdade de expressão convivia ambiguamente com uma forte rejeição às escolhas e demandas dos setores desfavorecidos da sociedade.

Diante da impossibilidade de analisar essa imprensa como um todo, foi eleito como objeto de pesquisa um órgão que, conforme a fonte diplomática acima, era bastante representativo do antiperonismo no Brasil: a revista semanal ilustrada $O$ Cruzeiro (1928-1975). Pertencente ao poderoso empresário da comunicação Assis Chateaubriand (1892-1968), esse periódico, especializado nas reportagens fotográficas (ou fotorreportagens), possuía, na década de 1940, a maior tiragem do país no seu segmento. ${ }^{8}$

Suas posições políticas, muitas vezes, oscilaram ao sabor dos interesses de seu temido proprietário, que construiu um enorme conglomerado de empresas jornalísticas,

\footnotetext{
${ }^{6}$ Vale destacar aqui o trabalho do historiador Marcelo Fernando Gonzalez da Costa (2004), que fez uma análise da repercussão da política externa do primeiro mandato de Perón (1946-1952) em dois jornais conservadores de Porto Alegre, o Correio da Manhã e o Diário de Notícias. De acordo com ele, os periódicos porto-alegrenses, com frequência, preferiram reproduzir notícias profundamente antiperonistas transmitidas pelas agências de notícias norte-americanas. Esses jornais contavam com poucos comentaristas políticos e quase não destacavam jornalistas para cobrir o país vizinho. Dessa forma, assumiram implicitamente muitas vezes o ponto de vista geopolítico dos Estados Unidos.

7 O termo liberal-conservador foi utilizado também para definir as posições do principal partido antivarguista do período, a UDN (União Democrática Nacional). Ver BENEVIDES, 1981.

${ }^{8}$ Ainda que não houvesse verificação independente, O Cruzeiro chegou a bater a marca de 720 mil exemplares semanais em 1954, número espantoso considerando que a população brasileira era de pouco mais de cinquenta milhões de pessoas no início da década de 1950.
}




os Diários Associados. Em 1945, por exemplo, Assis Chateaubriand apoiou a redemocratização e a candidatura do brigadeiro Eduardo Gomes (UDN). Com a vitória de Eurico Gaspar Dutra (PSD), porém, passou a respaldar, em linhas gerais, o novo governo (1946-1951). Em 1950, ele voltou a apoiar a nova tentativa frustrada de Eduardo Gomes. Não é de se estranhar, portanto, que, após o suicídio de Vargas (1954), carros de reportagem dos Diários Associados tenham sido atacados por populares e que, em Porto Alegre, dois de seus prédios tenham sido consumidos pelas chamas. Anos depois, a revista viria a se notabilizar pelo apoio explícito ao golpe militar de $1964 .{ }^{9}$ Em depoimento, José Medeiros, fotógrafo da publicação entre 1946 e 1962, assim definiu a posição ideológica do magazine:

Era acima de tudo uma revista de direita, feita para a classe média consumir. Muitas vezes havia reportagens sobre a fome, a repressão, resultado de interesses particulares de alguns de nós. Eram publicadas porque, em realidade, aquilo era uma bagunça incrível, não tinha um controle organizado. (MEDEIROS apud CARVALHO, 2001, p. 167)

A respeito do governo peronista, Chateaubriand teve uma postura de constante e profunda crítica, a ponto de um informe não assinado da embaixada argentina no Rio de Janeiro afirmar que ele nutria verdadeiro ódio pelo país. (Informe secreto apud ALMEIDA, 2005, p. 150) Para essa atitude, podem ter pesado tanto questões ideológicas quanto financeiras. Vale destacar, especialmente, a proibição da revista na Argentina durante o peronismo. Sabe-se que, mesmo em língua portuguesa, O Cruzeiro possuía uma tiragem considerável no país vizinho. (ACCIOLY, 1998, p. 159) Em uma reportagem de 1952, podia-se ler:

O CRUZEIRO, desde as nossas primeiras reportagens, passou a ser uma das revistas condenadas a não atravessar as fronteiras da Argentina. Muitos turistas passaram momentos desagradáveis e tiveram os seus exemplares desta publicação rasgados e atirados fora. Há pouco tempo, as revistas norteamericanas saíram do índex, mas esta continuou. (NASSER, O Cruzeiro, $13 / 09 / 1952$, p. 11)

Chateaubriand escreveu algumas vezes sobre o peronismo. Em uma dessas ocasiões, um texto de 1949, responsabilizou Perón pela crise econômica que se

\footnotetext{
${ }^{9}$ CAZARIN, E. A.; MENEZES, E. S. A mídia e o golpe de 1964: revista O Cruzeiro como aliada do discurso das forças militares. Conexão Letras, v. 9, 2014, p. 111-122.
}

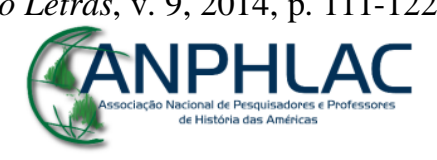

Revista Eletrônica da ANPHLAC, ISSN 1679-1061, №. 22, p. 258-295, Jan./Jun., 2017.

http://revista.anphlac.org.br 
avizinhava na Argentina e, num grande mosaico ideológico, comparou-o a Hitler, Mussolini e Juan Manuel de Rosas. Ele escreveu:

\begin{abstract}
Com um paroxismo de linguagem hitlerista ou mussoliniana, o ditador argentino tenta reproduzir o fenômeno dos seus dois colegas europeus, que pagaram com a vida as próprias tropelias, perpetradas com o nome de duas grandes comunidades civilizadas. E também Rosas aparece timidamente na fimbria do horizonte iluminado de uma luz baça de querosene, as profecias ingênuas do chefe do executivo do Prata e seus sequazes. O general Perón esquece que chegou atrasado. O último expresso de Berlim partiu e ele esqueceu de tomá-lo. Assediam-no em 1949, os roteiros de totalitarismo nazista que levariam a Alemanha à perdição ontem e à servidão política hoje. Está enfrentando o presidente argentino uma era que não é mais a sua, olvidando que a multidão de imponderáveis, que construíram a grandeza efêmera do tirano alemão foi a mesma que o levou a ruína. Com o grosseiro conteúdo ideológico de uma eloquência frenética o que o general Perón revive é uma instituição muito nossa conhecida e que é o irredutível caudilhismo americano. (CHATEAUBRIAND, O Jornal, 27/02/1949, p. 4)
\end{abstract}

De acordo com documento da embaixada argentina, a visão de Chateaubriand decorria, em parte, da defesa apaixonada que ele costumava fazer dos Estados Unidos e da presença do capital estrangeiro na economia brasileira. Ademais, seus negócios dependeriam bastante dos acordos publicitários firmados com grandes empresas multinacionais estadunidenses. (Informe secreto apud ALMEIDA, 2005, p. 87)

De acordo com levantamento realizado nesta pesquisa, O Cruzeiro publicou pelo menos 71 reportagens, crônicas e notas sobre a situação argentina entre 1946 e 1950. Considerando a totalidade de exemplares produzidos no período, em mais de um quarto deles Perón e sua atuação tiveram destaque. Esse número parece sintomático da intensa cobertura em torno do tema.

Nesse material, vale destacar as fotorreportagens profundamente antiperonistas assinadas por David Nasser, o repórter mais conhecido da redação de O Cruzeiro. É possível que algumas razões tenham contribuído para isso. A primeira delas foi seu notório posicionamento político conservador. ${ }^{10}$ Além disso, ele alegava ter sofrido os efeitos da censura peronista. Em sua vida, Nasser fez carreira paralela como compositor

\footnotetext{
${ }^{10}$ Crítico de Vargas e dos trabalhistas, Nasser era próximo de Carlos Lacerda e de outros nomes de destaque da direita brasileira. Embora não tenha se arriscado na televisão e tampouco na política institucionalizada, ele circulou livremente entre aqueles que apoiaram o golpe militar de 1964. Ver MORAES, Letícia Nunes de Góes. David Nasser e a conspiração de 1964. Revista Tempo Brasileiro, Rio de Janeiro, 158: 137/162, jul.-set., 2004.
}

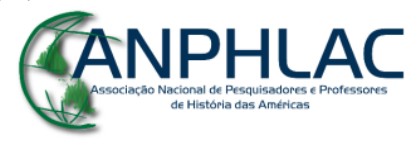

Revista Eletrônica da ANPHLAC, ISSN 1679-1061, №. 22, p. 258-295, Jan./Jun., 2017.

http://revista.anphlac.org.br 
e foi autor de músicas que se tornaram muito famosas, como "Canta, Brasil!", "Nêga do cabelo duro" e "Adeus ano velho". (MORAES, 2007, p. 30-35) Em 1954, Nelson Gonçalves gravou o tango "Carlos Gardel”, escrito por Nasser em parceria com Herivelto Martins. Apesar do enorme sucesso no Brasil, a canção não pôde ser reproduzida nem regravada na Argentina. O motivo, alega uma nota da época ( $O$ Cruzeiro, 19/06/1954, p. 58), seria retaliação às suas reportagens antiperonistas. A letra do tango não faz qualquer alusão à política justicialista.

Curiosamente, as primeiras fotorreportagens de $O$ Cruzeiro não foram tão críticas ao regime. Em “A mulher de Perón” (NASSER, O Cruzeiro, 01/06/1946, p. 616), a revista destacou principalmente o romance dos cônjuges da Casa Rosada. Há nessa primeira reportagem certa dissociação entre o discurso textual e o imagético. Em que pese as críticas do texto à ditadura do GOU, observadas apenas as fotos e as legendas a reportagem soa apologética ao peronismo. Nas imagens, Evita aparece glamorosamente bem vestida e com um sorriso educado, tal qual uma jovem atriz de Hollywood.

Apesar de algumas críticas feitas ao regime, confirma-se a impressão do historiador Marcelo Gonzalez da Costa (2004, p. 113) que viu em Perón e Evita, especialmente nessa fase, um "bom produto jornalístico, o que demonstra a proliferação de notícias e as manchetes contendo seus nomes". Com grandes reservas financeiras e enorme apoio popular, o governo argentino chamava atenção por sua rebeldia em relação aos Estados Unidos e por ter uma mulher considerada bonita dividindo informalmente a condução do país.

Em 1947, ao cobrir o encontro entre Dutra, Perón e Evita para a inauguração de uma ponte em Uruguaiana, o jornalista Geraldo de Freitas (O Cruzeiro, 14/06/1947, p. 56-62) destacou o bom clima do evento, malgrado este não ter sido mais do que uma "simples cerimônia inaugural” sem "as esperadas e sensacionais declarações dos três presidentes [sic], em conjunto, a respeito da política internacional”. Ainda assim, ele escreveu em tom otimista: "Felizmente nas Américas não desceu sobre os corações, como capas de chumbo, a desconfiança e o medo, que erguem fortalezas nas fronteiras, ao invés de estradas e pontes".



Revista Eletrônica da ANPHLAC, ISSN 1679-1061, №. 22, p. 258-295, Jan./Jun., 2017. http://revista.anphlac.org.br 
Ao longo dos anos, porém, a abordagem de O Cruzeiro começou a mudar profundamente. A partir de 1948, nenhuma matéria relativamente positiva sobre a experiência política justicialista foi mais publicada. Nessa segunda fase, caudilho foi uma palavra empregada com bastante frequência para designar o presidente platino. Dessa forma, buscava-se relacioná-lo a uma suposta condição intrinsecamente autoritária da América Latina.

No entanto, houve certa especificidade nas representações a respeito do peronismo e esta passou principalmente por sua associação com o nazismo. Mais do que o termo caudilho, outros adjetivos foram utilizados para descrever o governo platino, que foi chamado inúmeras vezes de "totalitário" e "hitlerista". Foi o que comentou David Nasser:

O general Perón não é um simples caudilho para uso interno [...] o atual regime da Argentina é tipicamente militarista e tem como programa os mesmos sonhos expansionistas que definiram o regime hitlerista. ( $O$ Cruzeiro, 30/09/1950, p. 26)

A representação não era exatamente nova. Durante a guerra, antifascistas argentinos já associavam continuamente o regime do GOU, integrado por Perón, ao Terceiro Reich. O golpe militar de 1943 abrira espaço para a atuação da direita nacionalista e dera início a uma nova onda antissemita no país. Apoiadores do novo regime, como a Alianza Libertadora Nacional (ALN), passaram a realizar ataques armados a indivíduos e instituições judias e comunistas. Não é coincidência, portanto, que, durante a campanha presidencial de 1946, a breve Unión Democrática, grupo de oposição à chapa encabeçada por Perón, tenha tido como lema principal "Pela liberdade, contra o nazismo". (CAPELATO, 2008, p. 268)

Durante a campanha, o Partido Laborista e o próprio Perón condenaram repetidas vezes os ataques antissemitas. Embora tenha conseguido poucos votos entre a comunidade hebreia, o apoio desse grupo cresceu ao longo dos seus anos de governo. Como registra Paradiso, a pragmática política peronista buscou compensações que pudessem evitar a rejeição da comunidade judia. Segundo ele,

A Argentina foi um dos países que recebeu maior quantidade de refugiados dessa origem, foi um dos primeiros a reconhecer o Estado de Israel [...] e

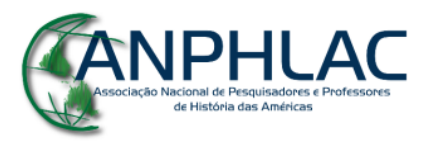

Revista Eletrônica da ANPHLAC, ISSN 1679-1061, №. 22, p. 258-295, Jan./Jun., 2017.

http://revista.anphlac.org.br 
houve numerosas personalidades judias no governo e entre os simpatizantes da força política que o sustentava. (PARADISO, 2002, p. 545)

Isso não evitou que, nas páginas de $O$ Cruzeiro, palavras como terror, medo e horror fossem bastante utilizadas para definir um regime que vigiaria constantemente seus opositores. Curiosamente, a população argentina foi poupada das críticas e quase sempre recebeu adjetivos positivos, como "grande", "bravo" e "amigo". Nessa chave interpretativa, nossos vizinhos não eram vistos como agentes políticos, mas como vítimas de um grande mal que impunha o silêncio absoluto, tal qual um "campo de concentração".

As fontes mostram que essa representação estava fortemente relacionada ao passado recente. Durante a Segunda Guerra, a Argentina manteve-se neutra por longos anos e declarou guerra ao Eixo apenas poucos meses antes do final da guerra. ${ }^{11}$ Além disso, o regime implantado por meio de um golpe em 1943 era apoiado por elementos ultranacionalistas e germanófilos. Com o fim do conflito, o país foi continuamente acusado de receber refugiados nazistas. Em uma reportagem da época, pode-se ler que "o melhor, ou o pior, do nazismo no mundo se encontra atualmente na Argentina, colaborando abertamente com o seu governo". (GUIMARÃES, O Cruzeiro, 01/04/1950, p. 48)

Desde os anos 1940, a forte propaganda antiperonista inflou números e criou algumas lendas em torno da ligação do justicialismo com o nazismo. Pouco se comentou que também sabiam desse tipo de imigração a Igreja Católica e a inteligência estadunidense e inglesa, que auxiliaram na criação de algumas rotas de fuga e buscaram 'desnazificar' a Alemanha e impedir técnicos nazistas de imigrar para a União Soviética. (CAVLAK, 2015)

\footnotetext{
${ }^{11}$ Essa postura, usada por alguns para apontar o vínculo entre peronismo e nazismo, deve ser compreendida em perspectiva histórica. Segundo Ranaan Rein (2015), a diplomacia platina possuía uma tradição em relação a essa posição que já fora adotada durante a Primeira Guerra e era apoiada por boa parte da população. Além disso, a Casa Rosada vinha manifestando resistências ao alinhamento geopolítico aos Estados Unidos em conferências pan-americanas desde o século XIX. Durante a guerra, a neutralidade fora fundamental para manter o abastecimento de trigo e carne à Grã-Bretanha, já que os navios argentinos eram menos atacados pelos submarinos nazistas. Por fim, é importante notar que a postura não beligerante foi mantida sucessivamente por quatro presidentes da República, sendo dois militares e dois civis. Ou seja, não foi idealizada e tampouco iniciada por Perón.
}

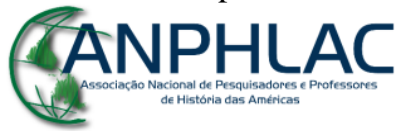


Segundo estimativa do historiador alemão Holger Mending, cerca de 80 mil alemães e austríacos chegaram à Argentina durante os anos peronistas (1946-1955). Calcula-se que três quartos deles mudaram-se em seguida para outros lugares, principalmente na América do Sul, ou retornaram à Europa. Aproximadamente 19 mil teriam se estabelecido definitivamente e se misturado à colônia alemã no país que já contava com cerca de 250 mil pessoas. (REIN, 2015)

Para o historiador israelense Ranaan Rein (2015), a chegada de refugiados nazistas na Argentina do pós-guerra deve ser compreendida levando-se em conta uma série de fatores. Em primeiro lugar, o país buscou, como muitos outros, atrair mão de obra qualificada dos países do Eixo, incluindo oficiais nazistas, que pudessem colaborar na industrialização, na modernização das Forças Armadas e no seu fracassado programa nuclear. No entanto, a política de vistos nem sempre foi dirigida pelo governo de modo claro e coerente, existindo numerosas autorizações expedidas por funcionários da imigração e cônsules que seguiram critérios diversos ou foram subornados. Também grande foi o número dos que chegaram com documentos falsos, obtidos junto à hierarquia da Igreja Católica e da Cruz Vermelha. Por fim, havia considerável receptividade em relação aos imigrantes do norte da Europa por parte das elites argentinas que desde o século XIX apontavam sua chegada como uma maneira de "melhorar" a população do país.

Mesmo depois da queda do peronismo, as relações do regime com o nazismo foram retomadas inúmeras vezes, com acusações insistentes por parte dos antiperonistas em relação a isso. Em 1999, uma comissão criada pelo governo Menem e composta por representantes do governo, diplomatas e historiadores argentinos e estrangeiros concluiu que entraram na Argentina depois de 1945, no mínimo, 180 criminosos de guerra. O número pode ser maior, mas essa foi a quantia que pôde ser comprovada pelos documentos levantados em diversos arquivos pela CEANA (Comisión para el Esclarecimiento de las Actividades del Nazismo en la Argentina).

Em seu informe final, a comissão indicou que tal processo imigratório era de conhecimento do governo Perón. No entanto, não existem sinais de que as autoridades argentinas tenham criado um programa específico para estimular intencionalmente a



Revista Eletrônica da ANPHLAC, ISSN 1679-1061, №. 22, p. 258-295, Jan./Jun., 2017.

http://revista.anphlac.org.br 
entrada de criminosos de guerra. Imperava na época o interesse em atrair técnicos que possibilitassem o desenvolvimento industrial e militar do país, ignorando a posição dos imigrantes na antiga hierarquia dos países do Eixo. Também colaborou para tal imigração o "clima receptivo" da política local, que combinava influências da imigração italiana e alemã, a existência de admiradores do fascismo e fortes sentimentos anticomunistas existentes na sociedade antes e depois da queda do Terceiro Reich.

Na década de 1940, porém, parecia natural aos opositores pensar que, se Perón seguia os passos de Hitler, também faria guerras para expandir seu domínio. Com base em tal perspectiva, sua política externa beligerante seria consequência de uma política interna totalitária. Esse desdobramento da argumentação antiperonista é bastante evidente nas fontes.

David Nasser, por exemplo, apresentou um controvertido discurso de 1943 atribuído ao líder platino. O documento, fartamente citado em diversos escritos antiperonistas, é descrito como "sensacional". Nele, há fartos elogios à Alemanha ("A luta de Hitler na paz e na guerra nos servirá de guia”) e trechos com planos explícitos para dominar a região:

Temos já o Paraguai; teremos a Bolívia e o Chile. Com a Argentina, Paraguai, Bolívia e Chile fácil será apoderar-se do Uruguai. Imediatamente, as cinco nações unidas atrairão facilmente o Brasil, devido a sua forma de governo [Estado Novo]. Caindo o Brasil, o continente sul-americano será nosso. Nosso domínio será uma realidade, realidade grandiosa, sem precedentes, nascida do gênio político e do heroísmo do Exército Argentino. (PERÓN apud NASSER, O Cruzeiro, 12/02/1949, p. 14)

Esse discurso, cuja autoria ainda é discutida pela historiografia (DEVOTO, 2005, p. 54), foi reiteradamente citado como prova das intenções militaristas do governo argentino em diversos meios de comunicação brasileiros. Nasser, como outros, não informou a fonte do documento. A possibilidade de fraude tampouco foi aventada por esses periódicos.

Deixando de lado os boatos, em que aspectos concretos parte da imprensa se baseou para promover tal imagem do governo peronista como intrinsecamente imperialista? A resposta parece estar relacionada a, pelo menos, três aspectos: o investimento nas Forças Armadas promovido por Perón, a valorização da memória de



Revista Eletrônica da ANPHLAC, ISSN 1679-1061, №. 22, p. 258-295, Jan./Jun., 2017.

http://revista.anphlac.org.br 
Juan Manuel de Rosas por aliados do regime e a divulgação de propaganda peronista no Brasil por meio de consulados e da embaixada no Rio de Janeiro.

Principalmente em seu primeiro mandato, o presidente argentino aumentou consideravelmente os gastos com as Forças Armadas, uma de suas bases de apoio político. Buscava, dessa forma, cativar a caserna e diminuir a desvantagem de equipamentos em relação ao Brasil, que recebera apoio técnico dos estadunidenses durante a Segunda Guerra.

Críticas sobre o suposto encaminhamento do regime para a guerra partiram com frequência da oposição existente dentro da própria Argentina. Nas páginas de $O$ Cruzeiro, por exemplo, Agustín Rodriguez Araya, deputado radical $^{12}$ exilado no Uruguai, condenou "a desenfreada corrida armamentista da Argentina" promovida pelo governo peronista, que desejaria "arrastar o país para um abismo que na certa reduzirá a Argentina ao mesmo estado dos países que fizeram a guerra na Europa”. (GUIMARÃES, O Cruzeiro, 01/04/1950, p. 52)

Comentários como esses chegaram aos poucos ao Brasil e acabaram adquirindo traços próprios. É o que mostra um relatório reservado produzido em dezembro de 1948 pelo então deputado federal (UDN-AL) Arnon de Mello (1911-1983). Ele foi à Argentina, entrevistou diplomatas e políticos oposicionistas e passou a acusar o regime justicialista de preparar uma guerra contra o Brasil. Com palavras muito parecidas com as de Araya, sua argumentação tinha como mote a ideia de que Perón buscava reviver a atuação imperialista de Juan Manuel de Rosas (1793-1877). A partir de então, essa associação tornou-se cada vez mais constante nos discursos dos políticos udenistas brasileiros. $^{13}$

\footnotetext{
${ }^{12}$ Radical no sentido de pertencer à União Cívica Radical, partido de oposição ao peronismo.

${ }^{13}$ A propósito, Rosas é um personagem que há muito alimenta paixões na historiografia e no mundo político argentino. Entre 1829 e 1832 e entre 1835 e 1852, ele foi governador de Buenos Aires e liderou despoticamente a Confederação Argentina, forma política adotada naquele momento na região. Desde os escritos de Sarmiento, Alberdi e Mitre, exilados por conta das perseguições do regime rosista, parte da historiografia argentina tendeu a destacar seu extremo autoritarismo. Durante o período peronista, muitos diários opositores buscaram associar o líder justicialista ao caudilhismo e à barbárie de Rosas. No Brasil, porém, a imagem de Rosas ganhou um sentido um pouco diferente do adotado comumente pela oposição argentina. Mais do que seu autoritarismo interno, destacou-se sobretudo sua política externa, tida como imperialista.
}

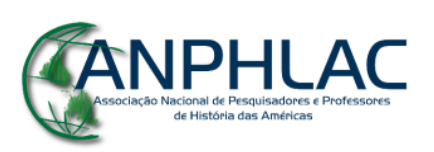


Esse resgate negativo da figura de Rosas não parece gratuito. Era de seu conhecimento a existência de intelectuais apoiadores do regime que, ainda que minoritários, glorificavam Rosas e defendiam o domínio argentino da região. Arnon de Mello (1949, p. 31) mencionou o fortalecimento do Instituto Juan Manuel de Rosas, antro dos intelectuais da direita nacionalista, e as palestras de Lúcio Manuel Moreno Quintana, professor universitário e ex-embaixador bastante influente, que estavam a difundir a ideia da reconstrução do Vice-Reino do Rio da Prata. Em seu retrato da Argentina justicialista, Arnon de Mello (1949, p. 33-34) escreveu: “[...] nunca, como agora, se glorificou tanto a Rosas na Argentina [...] Todos os cultores de Rosas estão em postos-chave do governo e do Partido Peronista. O movimento apaixona o Exército".

Embora exagerada, a descrição possui algo de realidade. De acordo com José Luis Beired (2001), havia desde os anos de 1920 intelectuais da direita nacionalista que defendiam o projeto da "Grande Argentina". Antiliberais, católicos e defensores da interferência militar no mundo político, apoiaram e receberam apoio da Alemanha nazista. De acordo com Beired (2001, p. 314), “embora não tivessem participado do golpe de $1943,[\ldots]$ o consideravam como algo que também lhes pertencia". Tanto que alguns participaram do governo do GOU por meio de cargos importantes nas áreas cultural e educacional. Em uma ótica revisionista, esses intelectuais consideravam o rosismo o período áureo do país por ter preservado tradições do período colonial, como o catolicismo e o hispanismo. Nessa perspectiva, a partir da derrota em Monte Caseros (1852), a nação teria entrado em um ciclo de decadência ao adotar de forma sistemática o liberalismo político e econômico. A situação poderia ser solucionada, porém, com a ascensão de um "caudilho moderno" que retomasse antigos valores e restaurasse o território do Vice-Reinado do Rio da Prata. (BEIRED, 2001, p. 318) Malgrado esses intelectuais dispusessem de pouco capital político efetivo, eles buscaram reinterpretar o passado de modo a justificar a intervenção militar argentina em países latinoamericanos.

Ciente da controvérsia que cercava a figura de Rosas, a propaganda oficial justicialista negou-se prudentemente a associá-lo a Perón. Preferiu promover a figura de

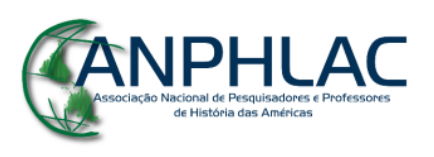

Revista Eletrônica da ANPHLAC, ISSN 1679-1061, №. 22, p. 258-295, Jan./Jun., 2017.

http://revista.anphlac.org.br 
Sarmiento, por exemplo. (CAPELATO, 2008, p. 258) Obras públicas e ferrovias nacionalizadas foram batizadas com nomes de vários presidentes, mas evitou-se usar o nome de Rosas, tão alvejado pela oposição.

A cautela do governo, porém, não impediu que a imagem de Rosas fosse constantemente utilizada pelos antiperonistas brasileiros. Aqui, no entanto, Rosas foi lido segundo uma chave diferente, na qual se explorava muito mais seu imperialismo do que seu autoritarismo em termos de política interna.

O relatório reservado do deputado udenista Arnon de Mello é especialmente importante, pois, apenas dois meses após ficar pronto, David Nasser assinou uma reportagem com conteúdo bastante similar. Ainda que não o cite diretamente, a similaridade de ideias parece indicar a proximidade entre líderes da UDN e veículos de comunicação como O Cruzeiro. ${ }^{14}$ Em Bancarrota argentina, Nasser (O Cruzeiro, 12/02/1949, p. 24) destacou o imperialismo do regime peronista inspirado em ideias nazistas. Com base em técnicas fascistas, Perón estaria transformando o país em um "grande circo" ao fomentar "o servilismo, a idolatria e o fanatismo entre as massas". Em outra reportagem semelhante, afirmou:

O governo argentino, que não exprime o pensamento do povo de sua terra,
prepara-se para uma aventura bélica, construindo apressadamente fábricas de
aviões e outras armas, estudando o preparo da bomba atômica e rasgando
estradas estratégicas na fronteira do Brasil. Como se sabe que toda a válvula
de escape de uma ditadura é a ação militar contra outra nação, o Brasil deve
estar preparado. Somos partidários de uma política de fraternidade e de
excelente vizinhança, mas é nosso dever advertir o povo, o Exército e o
Governo do Brasil contra o excesso de boa-fé. Se a Argentina se arma, não
será para combater na Coréia. Todas as nações têm o dever de se inquietarem
e exigirem explicações quando os seus vizinhos se armam até os dentes.
(NASSER, O Cruzeiro, 07/10/1950, p. 20)

Em consonância com a representação de um líder expansionista, Perón foi apontado continuamente como o grande causador de distúrbios na região ao apoiar políticos e governos sul-americanos simpáticos à Argentina. Nas palavras de Arnon de Mello (1949, p. 42), "sabe-se que os movimentos armados, as

\footnotetext{
${ }^{14}$ Conforme várias fontes, Nasser tinha boa entrada no circuito político da capital federal, cidade na qual vivia e onde a revista era produzida. Ver: MORAES, 2004.
} 
conspirações e agitações verificadas na Bolívia, Peru, Venezuela, Chile, Paraguai e Uruguai foram de inspiração argentina".

No campo das relações econômicas, a abordagem não foi diferente. "Tratados comerciais nitidamente imperialistas" foi como David Nasser (O Cruzeiro, 18/03/1950, p. 32) definiu em 1950 os acertos feitos entre Buenos Aires e La Paz. A dependência do Brasil em relação ao principal produto platino foi caracterizada por ele como "o jugo argentino do trigo". (NASSER, O Cruzeiro, 29/05/1948, p. 16)

Também parece ter contribuído bastante para essa imagem beligerante da Argentina a propaganda justicialista promovida a partir das próprias embaixadas e dos consulados argentinos. Trata-se de um tema muito pouco abordado pela historiografia, mas abundante nas fontes impressas. De acordo com o sociólogo argentino José Paradiso, tal propaganda era intencional e baseava-se numa concepção de Perón, de que, para além dos acordos com governos, era necessária uma ação orientada com os povos latino-americanos, "em cujo seio se procurava semear a ideia integracionista partindo da premissa de que eram [eles] os que realmente podiam impulsioná-la, impondo-se a conveniências setoriais ante as quais as autoridades costumavam sucumbir". (PARADISO, 2002, p. 570)

No caso do Brasil, a divulgação dos ideais justicialistas foi condenada frequentemente como interferência platina nos assuntos internos do país. Para alguns meios de comunicação brasileiros, a propaganda peronista seria uma forma de infiltração ideológica. As reportagens de $O$ Cruzeiro sobre o assunto estiveram relacionadas a pelo menos quatro aspectos dessa questão: caravanas de estudantes e trabalhadores para Buenos Aires, jornais supostamente financiados pelo regime, propaganda peronista no meio sindical e aproximação com políticos trabalhistas.

A respeito das caravanas, principalmente de universitários brasileiros, David Nasser afirmou que elas eram "recebidas de maneira estranhamente carinhosa" por Perón, que, além de financiar toda a viagem, encontrava-se pessoalmente com eles com bastante frequência. Nessas ocasiões, os alunos recebiam folhetos e livros sobre a doutrina justicialista, "camuflados de material de divulgação turística". Para ele, tais

\section{GANPHLAC}


gentilezas faziam parte de um plano bem arquitetado. Explica Nasser (O Cruzeiro, 07/05/1949, p. 28 e 78):

Existe, paralelamente, um movimento bem coordenado de propaganda, de formação de um exército de simpatizantes dentro das fronteiras do Brasil. Para a tomada de corações, em nada difere o plano de Perón do executado por Hitler antes da segunda guerra. Todas as caravanas brasileiras, sejam de estudantes ou de bancários, de oficiais de justiça ou de agricultores, passam a ser imediatamente consideradas hóspedes oficiais e recebem um tratamento especial. Os presentes cativam os visitantes e além dos souvenirs, acumulamse nos quartos de hotéis, roupas e objetos de uso pessoal. Os rapazes são levados a casas de ruidosa alegria, onde podem sentir a Buenos Aires amorosa e sensual, guardando da Argentina e especialmente de Perón, as mais agradáveis lembranças.

O assunto interessava a opinião pública nacional. ${ }^{15}$ Nas páginas de $O$ Cruzeiro, Vera Pacheco Jordão (09/07/1949, p. 3) destacou o assunto em uma crônica sobre a visita de professoras primárias à capital portenha. Lembrou a temerária interferência do regime argentino no ensino superior, que até aquele momento teria levado mais de mil e trezentos professores a serem demitidos ou se autoexonerado em protesto contra seu autoritarismo. Escreveu a cronista:

\begin{abstract}
Acabamos de sair do regime ditatorial que deixou profundas marcas em nosso povo, sobretudo na mocidade que cresceu ignorando os moldes democráticos. [...]. Ao apreciar o progresso argentino, o alto nível de vida em Buenos Aires, a excelente instalação das escolas, saberão os nossos jovens distinguir entre aquilo que é construção secular do povo argentino e de grandes estadistas, e a contribuição do governo peronista que se arroga todas as realizações? Mais ainda, saberão isolar o espírito e a letra [sic], discernindo a base falsa sob as aparências brilhantes, a deturpação do espírito escravizado, a negação da cultura avassalada pela política?

Só podemos deixar aqui esta advertência, para que abra os olhos daqueles que, demasiado prontos em admirar, queiram trazer de alheias terras sugestões aparentemente benfazejas mas contaminadas por um vírus indesejável.
\end{abstract}

Em relação aos periódicos, Nasser (O Cruzeiro, 07/05/1949, p. 28) apontou, em reportagem intitulada Espionagem de Perón no Brasil - Documento revelador, a existência de pelo menos dois jornais cariocas de baixa circulação supostamente subvencionados pelo governo platino. Embora não cite os títulos, sabe-se que um deles

\footnotetext{
15 Arnon de Mello (1949, p. 55) citou-o em seu relatório. De acordo com ele, Buenos Aires recebera apenas em julho de 1948 cerca de seiscentos estudantes brasileiros, a maioria secundaristas, em viagem patrocinada. Grupos de escreventes da justiça e bancários também teriam assistido a palestras com Perón.
} 
era $O$ Mundo, de propriedade do empresário Geraldo Rocha, tido como um dos “maiores amigos de Perón no Brasil”. (NASSER, O Cruzeiro, 12/02/1949, p. 13) Em consonância com a tese da infiltração justicialista, os jornais e jornalistas favoráveis ao governo argentino foram considerados "ponta de lança" do peronismo no Brasil e chamados "lavais mulatos e caboclos" (NASSER, O Cruzeiro, 07/05/1949, p. 28 e 78) e "lavais indígenas" (NASSER, O Cruzeiro, 30/09/1950, p. 25), em uma referência ao político francês Pierre Laval ${ }^{16}$. Sobre a atuação desses meios de comunicação, Nasser afirmou que estariam propositalmente promovendo a discórdia na vida política nacional para enfraquecer o país. Ele escreveu:

[...] Os peronistas estão fazendo no Brasil, contra as classes armadas, o parlamento, os homens públicos e os industriais, o mesmo, exatamente o mesmo, que fizeram os alemães na França; minando a confiança popular contra as forças vivas da nação, aquelas que poderiam fazer frente, de pronto, às ameaças externas. (NASSER, O Cruzeiro, 30/09/1950, p. 46)

Já o jornalista Arlindo Silva, em reportagem intitulada Ponta de lança dos descamisados, acusou o serviço diplomático argentino de distribuir aos sindicatos de trabalhadores de São Paulo livretos laudatórios ao peronismo, publicados em língua portuguesa. Para comprovar a acusação, a matéria foi recheada com fotografias dos folhetos entregues aos sindicatos, alguns já com o carimbo das instituições que os receberam. De acordo com Arlindo Silva, a escolha da capital paulista por parte do governo peronista estaria relacionada à existência de grande número de operários industriais naquela cidade. O jornalista comentou que "a tática adotada por ele [Perón] era a mesma que nós brasileiros já tivemos a desgraça de conhecer, e que é o ludibrio das massas por meio de concessões que se afiguram como grandes conquistas das mesmas”. (SILVA, O Cruzeiro, 31/01/1948, p. 38) Em uma legenda, a crítica ao varguismo apareceu de forma bem mais explícita: “Alguns [livretos] são escritos em castelhano, outros em português [...] e trazem expressões vagas, de sentido dúbio, lembrando os discursos do ex-ditador Vargas". (Idem, p. 37)

\footnotetext{
16 Tido como símbolo de traição, o político francês Pierre Laval (1883-1945) foi executado após condenação por alta traição e colaboração com os nazistas no período em que foi primeiro-ministro do governo de Vichy.
}

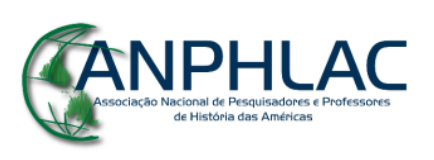

Revista Eletrônica da ANPHLAC, ISSN 1679-1061, №. 22, p. 258-295, Jan./Jun., 2017. http://revista.anphlac.org.br 
A propósito, quando questionado sobre a propaganda em outros países, Perón costumava afirmar que se o justicialismo ultrapassava as fronteiras isso não era culpa dos peronistas, pois as fronteiras não representam cercas para as ideias. (PARADISO, 2002, p. 537-538) Em outra ocasião, ele admitiu o uso da propaganda como arma de sua política externa e justificou-se ao afirmar que "não é possível empregar a resignação como única defesa aos ataques que se recebe”. (SAAVEDRA, 1998, p. 10) A muitos políticos e jornalistas brasileiros, tudo isso parecia muito suspeito.

Ao fazer uma intensa campanha de propaganda do peronismo, a Argentina acabava por passar a imagem de que, mais do que impulsionar a integração sulamericana, o país buscava conduzir o processo. Indiretamente, essa política de divulgação ajudou a fortalecer a representação de Perón como revivescência de Juan Manuel de Rosas. Essa é a conclusão da historiadora argentina Marisol Saavedra. De acordo com ela (1998, p. 9), a difusão do justicialismo no exterior, exitosa em certo sentido, contribuiu também para "aumentar os receios e desconfianças que já existiam em boa parte dos chilenos e brasileiros".

O imaginário antiperonista começou a se alterar no Brasil, principalmente nos anos finais da década de 1940, quando passaram a ser publicadas notícias desencontradas a respeito de ligações entre peronistas e membros do Partido Trabalhista Brasileiro (PTB). Como era de se esperar, essas denúncias se intensificaram à medida que se aproximavam as eleições presidenciais de 1950, com a participação de Getúlio Vargas. Em 1949, Nasser escreveu:

\footnotetext{
Uma aliança secreta é entabolada [sic] entre Perón, Luis Carlos Prestes e Getúlio. Fala-se numa linha telefônica direta entre S. Borja e Buenos Aires. Dos Estados Unidos vem uma informação que anuncia a visita "confidencial" do Sr. Getúlio Vargas a Juan Perón, em plena cidade de Buenos Aires. (NASSER, 12/02/1949, p. 16)
}

Não é de estranhar, portanto, que duas reportagens profundamente condenatórias ao justicialismo tenham sido publicadas justamente às vésperas do pleito, que se realizou em 03 de outubro de 1950. Na ocasião, Nasser (O Cruzeiro, 30/09/1950, p. 26) comparou o peronismo a "um foco de moléstia infecciosa e maligna". Na conclusão da reportagem, pode-se ler:



Revista Eletrônica da ANPHLAC, ISSN 1679-1061, №. 22, p. 258-295, Jan./Jun., 2017. http://revista.anphlac.org.br 
O governo argentino prestigiou a campanha do Sr. Getúlio Vargas no Brasil. Como provas materiais está a mudança de atitude e de ponto de vista de um jornal peronista do Rio, que passou do ataque ao elogio ao ex-ditador brasileiro. Existem indícios de que Perón forneceu vinte mil contos ao PTB para a campanha sucessória. Isto significa nada mais, nada menos, que a Argentina, com a eleição de SEU candidato à presidência deste país, terá em sua órbita mais uma nação americana. (NASSER, O Cruzeiro, 30/09/1950, p. 20)

Principalmente após a eleição de Getúlio Vargas em 1950, o regime platino passou a ser descrito como uma ameaça à democracia brasileira. A partir de notícias desencontradas, difundiu-se a noção de que, por meio de doações a campanhas eleitorais, treinamento militar e apoio armado, os peronistas estariam dispostos a ajudar os trabalhistas a criar no Brasil um regime semelhante ao justicialismo. Ou seja, para uma parte dos jornais e revistas, o regime argentino continuou representando um perigo. No entanto, não se esperava mais que Perón atacasse militarmente o Brasil governado por Vargas, um político que o chefe da Casa Rosada havia repetidamente elogiado. A ameaça agora seria a possível aliança entre os dois presidentes. Esse importante capítulo da história, no entanto, ultrapassa os interesses deste artigo.

Aparentemente distanciadas, a imprensa brasileira e a Embaixada Brasileira em Buenos Aires coincidiram naquele período no sentido de apontar o peronismo enquanto mal a ser combatido. Como se verá adiante, nosso aparato diplomático desde Buenos Aires também desenhou o regime político argentino como bastante prejudicial aos interesses nacionais.

Por meio dos ofícios enviados pela Embaixada, pode-se constatar uma visão de mundo que não só formatava a maioria das informações, de modo a recomendar o afastamento do governo Dutra em relação ao vizinho, como retroalimentava a própria maneira de encarar as relações políticas internas da Argentina. Assim, uma "diplomacia da obstrução" pairou no horizonte e, aliada às visões da imprensa estudadas acima, colaborou para o afastamento do peronismo em relação ao Brasil.

\section{GANPHLAC}

Revista Eletrônica da ANPHLAC, ISSN 1679-1061, №. 22, p. 258-295, Jan./Jun., 2017.

http://revista.anphlac.org.br 


\section{O imperialismo justicialista na documentação diplomática}

A Argentina, diferentemente do Brasil, emergiu da Segunda Guerra Mundial com sérios problemas de relacionamento com os Estados Unidos. Mais que isso, sua política interna se caracterizou enquanto antítese do que estava acontecendo em nosso país. Na Argentina, a experiência peronista iniciou-se acentuadamente pautada pela intervenção do Estado na economia, por uma política comercial protecionista, com a classe trabalhadora mobilizada pelos sindicatos oficiais e um braço político de expressão, o Partido Laborista.

Até o ano de 1950, a Embaixada Brasileira em Buenos Aires percebeu a Argentina como um país forte internamente e de posse de veleidades expansionistas em relação aos demais países da América do Sul, no contraponto à ordem internacional endossada pelos Estados Unidos. Ao Brasil do governo Dutra, coube proteger o sistema interamericano da força peronista, assumindo o papel de representante do liberalismo norte-americano na esfera da economia política das relações internacionais no subcontinente.

Pelos informes ${ }^{17}$ que a Embaixada Brasileira em Buenos Aires enviara ao Ministério das Relações Exteriores no Rio de Janeiro, pode-se perceber mais detidamente os motivos do afastamento diplomático do Brasil. Todavia, antes da análise dessa documentação, são necessárias algumas considerações a respeito da política varguista e posteriormente dutrista em relação ao corpo diplomático relativo à Argentina.

Em outubro de 1945, João Batista Lusardo era o embaixador brasileiro em Buenos Aires. Com o aumento do tensionamento político no país, Perón, que então acumulava os cargos de vice-presidente da República, Ministro do Trabalho e Previdência e Ministro da Guerra, recebeu ordem de prisão. Amigo de Lusardo, o líder argentino foi surpreendido pela proposta do diplomata brasileiro, que ofereceu asilo e proteção sem consultar o Itamaraty e o governo Vargas. Embora decidisse pela recusa,

\footnotetext{
${ }^{17}$ Escolhemos os ofícios - em lugar de telegramas, cartas telegramas e outros tipos de documentos - por conta de sua abrangência em relação às análises da realidade argentina.
} 
até por talvez antever os desdobramentos populares que sua prisão acarretaria, Perón jamais esqueceu esse gesto, prometendo a Lusardo uma lealdade assertiva, que de fato se mostrou concreta no decorrer dos anos. (CARNEIRO, 1978, p. 291)

Mesmo antes de firmar esse vínculo com o futuro presidente argentino, João Batista Lusardo já era conhecido na imprensa portenha como um "embaixador peronista”. Era igualmente amigo de Getúlio, homem ativo da Revolução de 1930, gaúcho e com longos serviços prestados tanto na Embaixada Brasileira no Uruguai quanto na Embaixada Brasileira na Argentina. Ou seja, acompanhara de perto a ascensão de Perón, com sinais claros de admiração e simpatia. De todos os embaixadores estrangeiros lotados em Buenos Aires, possivelmente foi o que mais desenvolveu intimidade e relações fraternas com a alta cúpula.

Mesmo sabendo disso, o presidente Dutra manteve Lusardo no cargo até fevereiro de 1947, quando o substituiu por Ciro de Freitas Valle, um quadro mais técnico e menos envolvido com a política partidária. Na ocasião, Lusardo reassumiu seu mandato de deputado federal pelo PTB do Rio Grande do Sul. Ele retornaria à embaixada em Buenos Aires após a vitória de Getúlio nas eleições presidenciais brasileiras de 1950.

Ocorre que, para o cargo de Ministro das Relações Exteriores, o novo governo de Dutra nomeou lideranças afeitas a um relacionamento de baixo perfil com a Argentina peronista, e de grande parceria respectivamente com os Estados Unidos, como João Neves da Fontoura e Raul Fernandes. Amado Luis Cervo caracterizou esse momento da diplomacia brasileira como "diplomacia da obstrução":

A documentação diplomática permite concluir que a política exterior do governo Dutra com relação à Argentina de Perón orientava-se pelos seguintes parâmetros de pensamento e ação: repulsa à ideia de integração regional, minguado esforço para contrabalançar a presença argentina nos países do Cone Sul e apoio à boa inserção da Argentina na comunidade pan-americana, sem melindrar o governo dos Estados Unidos. Com o tempo, essa política exterior tenderia ao confronto, por meio do que convencionamos chamar diplomacia da obstrução. Por seu lado, Perón buscava decididamente a cooperação bilateral e regional de modo, se possível, a criar um bloco de países que promovesse coletivamente o desenvolvimento e resistisse, na medida do necessário, à dominação econômica e política dos Estados Unidos sobre a América Latina. (CERVO, 2001, p. 157)

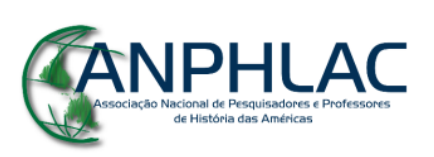

Revista Eletrônica da ANPHLAC, ISSN 1679-1061, №. 22, p. 258-295, Jan./Jun., 2017.

http://revista.anphlac.org.br 
Assim, o contexto aberto no Cone Sul após a Segunda Guerra Mundial foi se construindo através de uma díade, qual seja, a Argentina aprofundando internamente as reformas trabalhistas e, externamente, opondo-se ao posicionamento norte-americano, e o Brasil apontando para a direção contrária, com o governo Dutra intervindo e fechando sindicatos, implementando uma política liberal para investimentos privados e, externamente, rompendo com a URSS e situando-se ao lado de Washington.

Os primeiros ofícios enviados desde Buenos Aires para o Ministério das Relações Exteriores no Rio de Janeiro foram, em sua maioria, de elogios e vaticínios de um futuro próspero para o peronismo. Destacamos aqui todos os assinados por Lusardo, indicando quando o responsável for outro funcionário de embaixada. Em fevereiro de 1946, analisando o desempenho da economia argentina no ano anterior, este assim explanava:

Com as tendências determinadas pelo período bélico: grandes saldos positivos na balança comercial, plena atividade nos setores industriais e comerciais internos e, na ordem monetária, uma aparente acumulação de ouro e divisas no exterior e novos incrementos nos meios de pagamento. (Ofício n. 211, de 25 de fevereiro de 1946. Do Embaixador João Batista Lusardo para o Exc. Ministro João Neves da Fontoura.)

A estatização do Banco Central argentino foi uma medida de maior importância no sentido da subordinação da iniciativa privada ao novo tipo de gestão do aparelho de Estado que se estava construindo. Na visão da Embaixada, essa medida significou "o maior transcendente ato de centralização política", bem como "a constituição do maior controle de ordem econômica que poderia criar neste país". (Ofício n. 244, de 26 de março de 1946)

A Embaixada enfatizou como a vitória de Perón e a hegemonização do parlamento argentino por sindicalistas, a imensa maioria sem experiência com a atividade da política institucional, poderiam afetar as relações diplomáticas entre ambos os países. Sublinhou a possibilidade de novos desdobramentos dos atritos entre Estados Unidos e Argentina:

A República Argentina, que não participou da Guerra ao lado das nações unidas, tem orientado o escoamento dos produtos nobres de sua exportação para os países que lhe pode dar, em troca, artigos e produtos de que

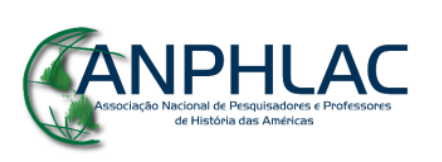

Revista Eletrônica da ANPHLAC, ISSN 1679-1061, №. 22, p. 258-295, Jan./Jun., 2017.

http://revista.anphlac.org.br 
urgentemente necessita [...] Pode a República Argentina privar o Brasil do trigo que dispõe para, com ele, alimentar as populações europeias? Interessa à República Argentina deixar de abastecer os países seus vizinhos e, alguns, até dependentes dela geograficamente, para mandar os seus produtos mais além de suas fronteiras? (Ofício n. 252, de 04 de abril de 1946. Do Embaixador João Batista Lusardo para o Exc. Ministro João Neves da Fontoura)

A Embaixada ficou atenta para o fechamento interno do regime peronista em relação aos canais institucionais de expressão das vozes oposicionistas. Numa conferência realizada na Confederação Geral do Trabalho, Perón afirmou que não havia espaço dentro da nova Argentina para quem não fosse "criollo", acrescentando que, "uma vez nos opusemos contra um imperialismo, nos oporemos também a outro, se necessário". (Ofício n. 393, mês econômico-financeiro-comercial, n. 7)

Juntamente com esses ofícios descritivos, podemos notar insinuações do peronismo para alianças na esfera econômica e política com o Brasil. Pelos recortes de jornais anexados aos ofícios, vislumbravam-se várias falas do presidente argentino em relação a uma aliança no Cone Sul, que se chamaria Pacto ABC (de Argentina, Brasil e Chile, tal como ensaiado na década de 1910 para dirimir tensões advindas do contexto anterior à Primeira Guerra Mundial na região). Lusardo se mostrava cauteloso nos comentários, recebendo em troca silêncio do Rio de Janeiro. Para Amado Cervo:

Enquanto esteve sob direção de Raul Fernandes, João Neves da Fontoura e Vicente Rao, o Itamaraty fazia na América do Sul o trabalho que a própria diplomacia americana se negou a executar, de torpedear a ação da Argentina de Perón, pensando assim agradar ao Departamento de Estado, quando lhe convinha, por todos os títulos, acompanhar a ação integracionista proposta por Perón, depurando-a - o que estava em condições de alcançar - de seu caráter hostil à potência hegemônica no hemisfério. (CERVO, 2001, p. 178179)

No final de 1946, a Embaixada Brasileira em Buenos Aires remeteu ao Rio de Janeiro um oficio tentando definir o que era o peronismo. Dizia tratar-se de uma clara hipertrofia do Estado aos moldes do nazismo e do fascismo. No caso, até pior porquanto misturado ao "caudilhismo", governo de um homem só chefiando "um aglomerado humano cuja passividade outorga a centralização individual do poder”. (Ofício n. 483, de setembro de 1946) Seguindo nessa toada, dizia-se que

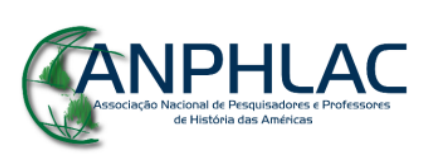

Revista Eletrônica da ANPHLAC, ISSN 1679-1061, №. 22, p. 258-295, Jan./Jun., 2017.

http://revista.anphlac.org.br 
A excepcional situação geográfica de Buenos Aires favorece, numa espécie de reimplantação do Vice Reinado do Rio da Prata, em domínio econômico, como recordei em estudos anteriores, e pressão política da Argentina sobre os povos vizinhos e, até certo ponto, seus tributários. (Ofício n. 483, de setembro de 1946. Ofício da lavra do primeiro secretário da Embaixada, Osvaldo Furst)

Sobre o poder bélico, sempre uma preocupação brasileira, assegurava:

Começa agora a grande campanha do que chama a entrada do país na era aeronáutica, comprando aviões, criando e estimulando companhias, fazendo pilotos e técnicos, projetando o aeródromo de Eceizer, que será monumental e um dos primeiros do mundo, rasgando estradas de rodagem entre todos os campos de aviação, escolas e bares, conquistando na paz a experiência da guerra que não fez. Todo seu enorme dinheiro é para adquirir maquinaria destinada à grande industrialização do país, armamentos e material bélico em geral para a marinha e para o Exército, navios mercantes, aviões comerciais, tudo, enfim, que ateste grandeza e prestígio. (Ofício n. 483, de setembro de 1946. Ofício da lavra do primeiro secretário da Embaixada, Osvaldo Furst)

Forçoso destacar aqui novamente como o contexto descrito estava em dissonância com o governo de Eurico Gaspar Dutra, contribuindo para desinteligências diplomáticas. Na opinião do Ministro da Fazenda brasileiro, Pedro Luís Correia e Castro, por exemplo, o Brasil era e permaneceria "um país essencialmente agrícola". (ALBUQUERQUE, 1996, p. 186) Na falta de uma política econômica de proteção aduaneira e utilização de divisas para a industrialização, o Brasil se enfraquecia economicamente justamente num momento de ascensão platina.

Para a Embaixada Brasileira em Buenos Aires, os objetivos da Argentina peronista eram claros:

Qualquer que seja a atividade internacional da Argentina, o seu objetivo é o Brasil [...] As forças que a Argentina pode usar, direta ou indiretamente contra o Brasil, seguramente usará [...] Desde que o General Perón assumiu o governo, a 4 de junho, o Brasil não recebeu um só quilo de trigo da Argentina. Os apelos do Brasil, raciocinemos claro, chegaram ao desespero, pois a falta do cereal gerava, à margem do problema econômico, a questão social, provocando desentendimentos gerais e evidentemente a sublevação das massas incitadas pela propaganda comunista. Neste trágico momento para o Brasil, a Argentina se mostrou irredutível. Esse fato confirma, a República Argentina tem interesse em que haja pobreza e descontentamento no Brasil. Enfraquecidas as fontes de produção no Brasil, deprimida pela fome a maior parte de sua população, minado seu trabalhador pela propaganda comunista, o Brasil entraria em fase de desanimo e desgraça, na proporção inversa da riqueza, do bem estar e da projeção internacional da Argentina. (Ofício "secreto", de 16 de outubro de 1946. Ofício da lavra do



Revista Eletrônica da ANPHLAC, ISSN 1679-1061, №. 22, p. 258-295, Jan./Jun., 2017.

http://revista.anphlac.org.br 
primeiro secretário da Embaixada, Osvaldo Furst, para Samuel de Souza Leão Gracie)

Esses documentos desabonadores para o governo argentino eram assinados por Osvaldo Furst, primeiro secretário da embaixada e extremamente crítico ao peronismo. Uma perspectiva bastante diferente de Lusardo, não obstante em sintonia com a opinião da classe dirigente brasileira naquele momento. Na verdade, não interessava a Perón o conflito com o Brasil, tampouco "sublevações das massas instigadas por comunistas" ou a "depressão pela fome". Entendemos que essa leitura de Furst, claramente diferente de Lusardo, denotava uma estrutura de pensamento para com a Argentina semelhante aos jornais aqui analisados, ou seja, a caracterização de um governo nacional-reformista como imperialista e subversor da ordem.

No início de 1947, a Embaixada Brasileira vaticinava como seria o futuro imediato da Argentina:

\footnotetext{
Industrialização, produção e comércio, esse é o triângulo a partir de 1 de janeiro próximo, mesmo com o plano quinquenal ainda sob dependência de aprovação do legislativo, que fará girar em torno de si toda a atividade argentina. O ano de 1947 será para a República Argentina cheia de recursos da terra, de meios em dinheiro, em títulos e em créditos, de audácia e anseio de crescer, um ano de evidente prosperidade. (Ofício n. 17, de 14 de janeiro de 1947. De Ciro de Freitas Valle para Raul Fernandes)
}

Um país fechado politicamente e desfrutando de uma prosperidade ímpar, voltado em sua maioria para o fortalecimento econômico e militar. Essa parecia ser a sugestão do aparato diplomático brasileiro. Os militares argentinos seriam os mais bem capacitados do subcontinente, sobretudo a Aeronáutica, "talvez a mais eficiente e poderosa da América Latina”. (Ofício n. 17, de 14 de janeiro de 1947. Ciro de Freitas Valle para Raul Fernandes) Em um dos últimos ofícios de janeiro de 1947, após analisar aspectos da economia argentina, a Embaixada Brasileira destacou em letras garrafais que em pouco tempo a Argentina se transformaria "NO PAÍS MAIS INDUSTRIALIZADO DA AMÉRICA DO SUL”. (Ofício n. 41, de 30 de janeiro de 1947) Também se tratava da conquista dos vizinhos pela diplomacia platina:

Não é mistério para ninguém que a orientação da política argentina, na esfera internacional, foi sempre de chamar para si uma espécie de tutela do maior número de nações vizinhas, de modo a aparecer, nas conferências

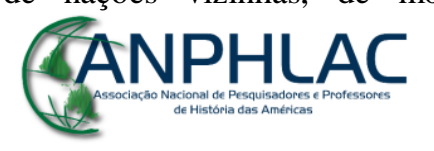

Revista Eletrônica da ANPHLAC, ISSN 1679-1061, №. 22, p. 258-295, Jan./Jun., 2017.

http://revista.anphlac.org.br 
americanas, escudadas por essas. (Ofício n. 96, de 13 de março de 1947. De Ciro de Freitas Valle para Raul Fernandes)

Ao comentar o que seria a tradição argentina na política internacional, a Embaixada castigava:

Há, porventura, quem dê notícias lógicas da "tradição argentina", além do que se manifesta no enlouquecido nacionalismo [...] Será tradição aprovar as convenções interamericanas e não as ratificar? Tentar a hegemonia material para chegar através dela à hegemonia política na América Latina? [...] Tradição envolve fidelidade a um sistema jurídico, político ou religioso. Nas práticas internacionais, a Argentina, país cuja formação só agora se consolida, não expressou fé a qualquer sistema. Assina e renega, aprova e não ratifica. Pacifista, arma-se. Bom vizinho, não teve solidariedade com o Brasil em qualquer dos momentos graves para esse. Árbitro, foi o que lucrou, sem riscos, na Guerra do Chaco. É isso tradição? (Ofício n. 101, de 18 de março de 1947. De Ciro de Freitas Valle para Raul Fernandes)

O Embaixador Ciro de Freitas Valle, responsável por esses ofícios, fora descrito por Lusardo como "udenista até a medula, sinônimo de antigetulismo e antiperonismo". (CARNEIRO, 1978, p. 319) E com a UDN em evidência no cenário nacional, percebemos a concatenação tanto no exterior quanto no país de uma política clara de defenestração do peronismo.

Daí, o assunto seguiu para a dominação de tecnologia atômica, então o maior temor de todos os ligados ao crescimento da capacidade de destruição de um país sobre o outro:

Três medidas do Congresso Nacional Argentino, destinadas a proporcionar fundos, equipamentos e técnicos para o programa de investigação atômica, foram classificadas recentemente como "legislação militar secreta" [...] aplicou-se lhes a cláusula do plano quinquenal que tornam "secretos e ilimitados" os gastos da defesa nacional. O primeiro parágrafo da lei que institui o "centro atômico" do Ministério da Guerra da Argentina "reclama" a colaboração de todos os laboratórios do país em que já se realizam investigações cientificas com relação à energia atômica. (Ofício n. 67 e 118, de 28 de fevereiro e 31 de março de 1947. De Ciro de Freitas Valle para Raul Fernandes)

Em outro relatório, destacou-se a seguinte passagem: "Se há, pois, na América do Sul, indústria de guerra preparada, com direção consciente e autônoma, é a da República Argentina". (Ofício do mês militar-naval-aéreo, n. 7)

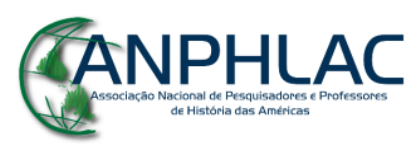

Revista Eletrônica da ANPHLAC, ISSN 1679-1061, №. 22, p. 258-295, Jan./Jun., 2017.

http://revista.anphlac.org.br 
$\mathrm{Na}$ prática, por informações da própria Embaixada, o regime argentino foi estabelecendo diretrizes de entendimento com o Brasil. No plano simbólico, várias escolas públicas importantes de Buenos Aires haviam sido rebatizadas em homenagem a heróis brasileiros:

José Bonifácio de Andrada e Silva, Duque de Caxias, Quintino Bocaiúva, Osvaldo Cruz e Rui Barbosa [...] ao lado de José de San Martin, Bernardino Rivadavia, Justo José de Urquiza, Estrada, Florêncio Amighino, Bartolomé Mitre, etc, isto é, na mais honrosa companhia que os filhos deste país poderiam proporcionar ao Brasil. (Ofício n. 283, de 22 de abril de 1946. De João Batista Lusardo para João Neves da Fontoura)

Em 1947, o maior esforço do pessoal diplomático argentino recaiu na organização de um encontro entre os presidentes Perón e Dutra na fronteira entre Uruguaiana e Passos de Los Libres. Nessa ocasião, os peronistas solicitaram uma longa lista de atividades, que incluiria alongamento de linhas de créditos, aumento do fluxo comercial, criação de novos intercâmbios de mercadorias, protocolos culturais, ou seja, vários dias de discussões e acertos, com presença maciça de políticos, sindicalistas e populares, auxiliados por uma gigantesca comitiva de imprensa. A cereja do bolo seria um discurso em conjunto e a assinatura de um tratado político que indicaria a liderança compartilhada de Brasil e Argentina nos problemas internacionais da região.

Naturalmente, todo esse esforço foi debelado pela diplomacia brasileira, que categoricamente tergiversou todas essas iniciativas e se limitou ao básico de praxe, negando, por ordens expressas de Dutra, qualquer palavra a respeito de "blocos políticos ou comerciais". Ciro de Freitas Valle assim se expressou a respeito do encontro:

\footnotetext{
Imediatamente, de acordo com as ordens de vossa excelência (o Ministro das Relações Exteriores do Brasil, Raul Fernandes - nota do autor), encarei a questão de limitar-se o encontro a um dia, de manhã a noite [...] O encontro seria simbólico e os presidentes pouco teriam a dizer-se. (Ofício n. 142, de 17 de abril de 1947. De Ciro de Freitas Valle para Raul Fernandes)
}

No mesmo ofício, Valle assinalou que havia pedido ao chanceler argentino "pouca oratória" e que "só os presidentes falassem".

Em meio aos insucessos argentinos de aproximação com os brasileiros, Perón subiu o tom na sua política internacional e, no segundo semestre de 1947, decretou que seu país assumiria uma Terceira Posição em política externa, não alinhada nem aos

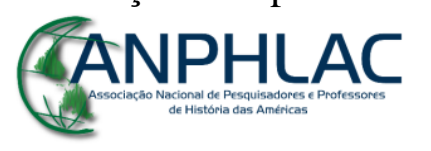

Revista Eletrônica da ANPHLAC, ISSN 1679-1061, №. 22, p. 258-295, Jan./Jun., 2017.

http://revista.anphlac.org.br 
norte-americanos e nem aos soviéticos. Com a Guerra Fria já se desenvolvendo no horizonte, mais os tratados comerciais e políticos que Buenos Aires lograra fechar com os países do entorno regional - com exceção do Brasil -, potencializou-se a repercussão negativa dessa iniciativa junto ao governo brasileiro.

Vale destacar que naquele momento os EUA haviam proibido a utilização de recursos disponibilizados aos europeus para comprarem produtos argentinos. A Argentina então se direcionava para Moscou e a zona de influência soviética no mesmo período em que o Brasil de Dutra cassava os comunistas e rompia de maneira unilateral as relações diplomáticas com a URSS.

Assim sendo, foi nessa toada de afastamento e marginalização que seguiram os diversos ofícios de Buenos Aires para o Brasil até em torno de 1949, destacando quase sempre o caráter agressivo e de perfídia do governo peronista, inviabilizando qualquer tipo de acordo mais profundo que pudesse ser concretizado naquele momento.

\section{Considerações finais}

Apesar da insistência da diplomacia argentina, o Brasil evitou acordos diplomáticos substanciais no período e manteve seu alinhamento geopolítico com os Estados Unidos. Ao que tudo indica, colaboraram para isso não apenas a intensa propaganda antiperonista promovida pelas oposições argentinas, pela diplomacia estadunidense e as agências de notícias internacionais, mas também a atuação de uma parte dos jornalistas e de diplomatas brasileiros, evidenciada nas fontes históricas destacadas nas páginas anteriores.

Ainda que a Argentina não tenha entrado em conflito armado com nenhum país durante os anos de 1946 a 1950, esses setores trataram de difundir continuamente a imagem de que o regime justicialista era simpático ao Terceiro Reich e que naturalmente imitaria seus propósitos expansionistas. Nesse sentido, difundiram-se muitas acusações de ligações secretas do peronismo com o nazismo, denúncia reverberada pela diplomacia e pelas agências de notícias norte-americanas.

\section{CANPHLAC}


Tendo em vista a historiografia recente, é importante colocar tais afirmações em perspectiva. Se por um lado o governo argentino não se preocupou em identificar nem impedir a entrada de criminosos de guerra nazistas, há que se ter em conta que, por outro lado, nunca houve um programa deliberado de atração ou proteção desse grupo específico, composto em muitos casos por imigrantes que chegaram ao país com passaportes falsos e misturando-se à multidão de refugiados de guerra. $\mathrm{O}$ apoio de uma parte da comunidade judaica ao governo justicialista, como apontado por Raanan Rein, é mais um aspecto que mostra que a realidade era bem mais complexa do que aquela difundida nas fontes analisadas. (REIN, 2015)

Além dos boatos, tão comuns em guerras de propaganda, colaboraram para a imagem da Argentina imperialista fatores concretos indicados tanto nos jornais como nos ofícios diplomáticos brasileiros do período. Apontava-se com preocupação o alto investimento platino nas Forças Armadas, a valorização da memória de Juan Manuel de Rosas por grupos de extrema-direita que respaldaram inicialmente o justicialismo e a divulgação de propaganda peronista dentro do Brasil. Esta estaria ocorrendo por meio de caravanas de estudantes e trabalhadores financiadas pela Casa Rosada, de jornais brasileiros subsidiados pelo regime, de livros com explícito conteúdo ideológico distribuídos no meio sindical e da aproximação silenciosa com políticos do PTB.

A última acusação, a de uma aliança secreta entre peronistas e petebistas para estabelecer uma república sindicalista no Brasil, foi muito mais frequente a partir do ano de 1950, quando Vargas, político que Perón disse repetidas vezes admirar, venceu as eleições presidenciais.

Como pano de fundo de todas essas representações negativas, é possível detectar entre os setores sociais analisados certa rejeição ideológica mais ampla àqueles regimes latino-americanos nacionalistas apoiados pelas massas e que, em determinados momentos, assumiram formas autoritárias. ${ }^{18}$ Críticos de Vargas, considerado um líder autoritário e demagogo, muitos jornalistas e diplomatas brasileiros viam o peronismo

\footnotetext{
${ }^{18}$ Para ficar em apenas um exemplo, um dos embaixadores brasileiros em Buenos Aires (1947-1948), Ciro de Freitas Valle, afirmou que Perón errava ao pagar altos salários a peões que "imaginam serem explorados" e que os trabalhadores argentinos recebiam "talvez mais do que necessitam" para viver. (CAVLAK, 2008, p. 118)
}

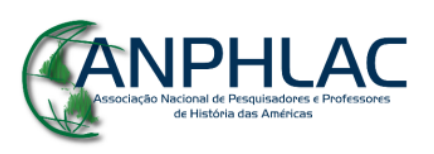

Revista Eletrônica da ANPHLAC, ISSN 1679-1061, №. 22, p. 258-295, Jan./Jun., 2017. http://revista.anphlac.org.br 
como um regime inspirado no Estado Novo getulista. Não se pode deixar de levar isso em conta.

Por fim, vale destacar que o momentâneo descompasso entre a situação política e econômica dos dois países conspirou para o afastamento. O Brasil de Dutra tendeu para o liberalismo na economia e o conservadorismo na política com o governo federal intervindo em sindicatos, rompendo relações com a URSS e empastelando movimentos radicais. Em termos de política externa, seu resultado foi, na expressão de Gerson Moura (1990), um “alinhamento sem recompensa” aos Estados Unidos. Já a Argentina de Perón, sobretudo naquela segunda metade dos anos 1940, apostou em uma série de estatizações e na criação de direitos sociais amparados na ótima situação econômica da nação no pós-guerra. O justicialismo trouxe mudanças políticas profundas, como o voto feminino, a intensa participação sindical e uma diplomacia não alinhada às superpotências. Tais mudanças ocorreram, não se pode esquecer, em um contexto cada vez mais autoritário.

Enquanto a política externa peronista tentou romper o isolamento imposto pelos norte-americanos, construindo novos parceiros e inserções, a "diplomacia da obstrução" promovida pelo Brasil boicotou tal seara e bloqueou todas as iniciativas que pudessem questionar o status quo internacional no entorno regional.

As visões negativas produzidas pela grande imprensa e pela diplomacia foram expressões desse descompasso, potencializado por rixas históricas e desconfianças de longa data. Assim, os atores sociais analisados foram, cada um a sua maneira, expressões de uma conjuntura nacional que caminhou em sentido contrário ao do nosso principal vizinho.

As representações analisadas ao longo do trabalho tornaram-se tão fortes e arraigadas que, mesmo nos anos 1950, numa nova conjuntura com Vargas de volta ao poder, foi sobremaneira difícil ultrapassar as desconfianças em nome de eventuais interesses coletivos para ambos os países.

\section{GANPHLAC}




\section{Fontes documentais}

FREITAS, Geraldo de; REGATO, Angelo. Novas pontes ligam a América. O Cruzeiro, Rio de Janeiro, 14 de junho de 1947, p. 56-62.

CHATEAUBRIAND, Assis. O Fim de uma Aventura política. O Jornal, Rio de Janeiro 27/02/1949, p. 4.

GUIMARÃES, Josué; KEFFEL, Ed. A tirania pelo medo - Os fugitivos de Perón (parte 1). $O$ Cruzeiro, Rio de Janeiro, $1^{\circ}$ de abril de 1950, p. 41, 42, 48 e 52.

JORDÃO, Vera Pacheco. Nuestra Argentina. O Cruzeiro, Rio de Janeiro, 09 de julho de 1949, p. 3.

LACERDA, Carlos. Traição à vista. Tribuna da Imprensa. Rio de Janeiro, 10 de agosto de 1950, p. 4.

MELLO, Arnon de. Relatório reservado sobre a situação político-militar da Argentina e suas relações com o Brasil. Rio de Janeiro, 1949. Classificação CPDOC/RJ: 327(81:82)/M527r.

[Nota sem assinatura] O CRUZEIRO, Rio de Janeiro, 19/06/1954, p. 58.

NASSER, David; MANZON, Jean. A mulher de Perón. O Cruzeiro, Rio de Janeiro, $1^{\text {o }}$ de junho de 1946, p. 6, 8-16.

NASSER, David; SCLIAR, Salomão. Pão nosso de cada dia - A vergonha do trigo. $O$ Cruzeiro, Rio de Janeiro, 29 de maio de 1948, p. 8-14 e 16.

NASSER, David; MANZON, Jean. Bancarrota Argentina. O Cruzeiro, Rio de Janeiro, 12 de fevereiro de 1949, p. 12- 20 e 24.

NASSER, David. Espionagem de Perón no Brasil - Os agentes argentinos no Rio. $O$ Cruzeiro, Rio de Janeiro, 30 de abril de 1949.

NASSER, David. Espionagem de Perón no Brasil - Documento revelador. O Cruzeiro, Rio de Janeiro, 07 de maio de 1949, p. 28 e 78.

NASSER, David; MANZON, Jean. A rebelde Bolívia - Sangue, estanho e dinamite. $O$ Cruzeiro, Rio de Janeiro, 18 de março de 1950, p. 12-22, 28, 32 e 96.

NASSER, David. Marcado por Perón - o drama argentino. O Cruzeiro, Rio de Janeiro, 30 de setembro de 1950, p. 25, 26 e 46.

\section{GANPHLAC}

Revista Eletrônica da ANPHLAC, ISSN 1679-1061, №. 22, p. 258-295, Jan./Jun., 2017.

http://revista.anphlac.org.br 
NASSER, David. Perón insulta o Brasil: 'Uma república de bêbedos'. O Cruzeiro, Rio de Janeiro, 07 de outubro de 1950, p. 15, 16, 17, 18 e 20.

NASSER, David; KEFFEL, Ed. Perón denunciado às Nações Unidas. O Cruzeiro, Rio de Janeiro, 13 de setembro de 952.

OFÍCIO n. 211, de 25 de fevereiro de 1946.

OFÍCIO n. 244, de 26 de março de 1946.

OFÍCIO n. 252, de 04 de abril de 1946.

OFÍCIO n. 393, mês econômico-financeiro-comercial, n. 7, Junho de 1946.

OFÍCIO n. 483, de setembro de 1946.

OFÍCIO "secreto", de 16 de outubro de 1946.

OFÍCIO n. 17, de 14 de janeiro de 1947.

OFÍCIO n. 41, de 30 de janeiro de 1947.

OFÍCIO n. 96, de 13 de março de 1947.

OFÍCIO n. 101, de 18 de março de 1947.

OFÍCIO mês militar-naval-aéreo, n.10, 1947.

OFÍCIO mês militar-naval-aéreo, n.7, julho de 1947.

SILVA, Arlindo. Ponta de lança dos descamisados. O Cruzeiro, Rio de Janeiro, 31 de janeiro de 1948, p. 36-28 e 56.

\section{Referências bibliográficas}

ALBUQUERQUE, José Augusto Guilhon (Org.). Sessenta Anos de Política Externa Brasileira (1930-1990). Vol. 1. São Paulo: EDUSP, 1996.

ACCIOLY NETO, Antonio. O Império de Papel - Os bastidores de O Cruzeiro. Porto Alegre: Sulina, 1998.

ALMEIDA, Hamilton. Sob os olhos de Perón: o Brasil de Vargas e as relações com a Argentina. Rio de Janeiro: Record, 2005.

BANDEIRA, Luiz Alberto Moniz. Brasil, Argentina e Estados Unidos: conflito e integração na América do Sul (da Tríplice Aliança ao Mercosul), 1870-2007. $3^{\text {a }}$ edição rev. e amp. Rio de Janeiro, Civilização Brasileira, 2010.

\section{GANPHLAC}

Revista Eletrônica da ANPHLAC, ISSN 1679-1061, №. 22, p. 258-295, Jan./Jun., 2017.

http://revista.anphlac.org.br 
BEIRED, Jose Luis Bendicho. A 'Grande Argentina': um Sonho Nacionalista para a Construção de uma Potência na América Latina. Revista Brasileira de História (Online), São Paulo, v. 21, n. 42, 2001.

BENEVIDES, Maria Victoria de Mesquita. A UDN e o udenismo - ambiguidades do liberalismo brasileiro (1945-1965). Rio de Janeiro: Paz e Terra, 1981.

BOHOSLAVSKY, Ernesto. Antivarguismo y antiperonismo (1943-1955): similitudes, diferencias y vínculos. Anuario digital (Esc. Historia, F., H. y A. de la UNR), Universidad Nacional de Rosário, no. 24, 2012, p. 73-97.

CAPELATO, Maria Helena Rolim. Multidões em Cena: Propaganda Política no Varguismo e no Peronismo. $2^{\mathrm{a}}$ edição. São Paulo: Editora UNESP, 2008.

CARNEIRO, Glauco. Lusardo: O Último Caudilho. Rio de Janeiro: Nova Fronteira, 1978.

CARVALHO, Luiz Maklouf. Cobras Criadas: David Nasser e O Cruzeiro. São Paulo: editora SENAC, 2001.

CAVLAK, Iuri. A politica externa brasileira e a Argentina Peronista (1946-1955). São Paulo, Annablume, 2008.

- Nazismo na América do Sul: A questão do peronismo. Boletim Tempo Presente (UFRJ), v. 8, 2013.

CAZARIN, E. A.; MENEZES, E. S. A mídia e o golpe de 1964: revista O Cruzeiro como aliada do discurso das forças militares. Conexão Letras, v. 9, p. 111-122, 2014.

CERVO, Amado Luís. Relações Internacionais da América Latina: Velhos e Novos Paradigmas. Brasília: IBRI, 2001.

COSTA, Marcelo Fernandes González da. As repercussões da política externa Argentina no primeiro Governo Perón (1946-1952) na imprensa Sul-Rio-Grandense. Dissertação de mestrado, São Leopoldo, Universidade do Vale do Rio dos Sinos (UNISINOS), 2004.

DEVOTO, Leonor Machinandiarena de. Las relaciones com Chile durante el Peronismo: 1946-1955. Buenos Aires, Lumière, 2005.

MORAES, Letícia Nunes de. Cotidiano e Política em Carmen da Silva e David Nasser (1963-1973). Tese de doutorado. Universidade de São Paulo, 2007.

\section{CANPHLAC}

Revista Eletrônica da ANPHLAC, ISSN 1679-1061, №. 22, p. 258-295, Jan./Jun., 2017.

http://revista.anphlac.org.br 
. David Nasser e a conspiração de 1964. Revista Tempo Brasileiro. Rio de Janeiro, 158: 137/162, jul.-set., 2004.

MOURA, Gerson. O alinhamento sem recompensa: a política externa do governo Dutra. Textos CPDOC, Rio de Janeiro: MRE, FGV/CPDOC, 1990.

NÁLLIN, Jorge A. Las raíces del antiperonismo. Orígenes históricos e ideológicos. Buenos Aires: Capital Intelectual, 2014.

PARADISO, José. Vicisitudes de una política exterior independiente. In: TORRE, Juan Carlos (Org.). Nueva Historia Argentina. Tomo VIII. Los años peronistas (1943-1955), Buenos Aires, Ed. Sudamericana, 2002.

REIN, Raanan. Los muchachos peronistas judios. Los argentinos judíos y el apoyo al Justicialismo. Buenos Aires: Sudamericana, 2015. Disponível em: www.amazon.com. Acesso em: 28 de outubro de 2016.

SAAVEDRA, Marisol. Peronismo y antiperonismo en Chile y Brasil. Todo es Historia, no 369, abril de 1998, p. 8-34.

SEBASTIANI, Marcela García. Los antiperonistas en la Argentina peronista. Radicales y socialistas en la política argentina entre 1943 y 1951. Buenos Aires, Prometeo Libros, 2005.

SPINELLI, María Estela. Los vencedores vencidos. El antiperonismo y la "revolución libertadora”. Buenos Aires, Biblos, 2005.

TORRE, Juan Carlos. Introducción a los años peronistas. In: Juan Carlos Torre (Dir.) Nueva Historia Argentina. Tomo VIII. Los años peronistas (1943-1955). Buenos Aires, Ed. Sudamericana, 2002.

\section{GANPHLAC}

Revista Eletrônica da ANPHLAC, ISSN 1679-1061, №. 22, p. 258-295, Jan./Jun., 2017. http://revista.anphlac.org.br 